\title{
Detection of Severity of Chronic Cough in Elders and Children using Machine Learning
}

\author{
R,Velvizhi, D.Jayapriya, N. Priya
}

\begin{abstract}
Cough is a prevalent symptom of many illnesses of the respiratory system. The assessment of its intensity and event frequency could provide useful clinical data in the assessment of chronic cough patients. The MEMS vibration sensor is placed in neck either as batches or robes. The band-like filter patch was put on the body of the patient. Sensor is driven by batteries that allow patient mobility and connect to a smartphone phone. Smartphone transmits information to a cloud-based health platform that provides additional information and alerts medical staff. The machine learning algorithms collect and analyze the sound of the coughs to personalize it to the user based on its pitch and sound profile, which is unique to each person based on the size and capacity of his or her lungs. When coughing indicates an impending attack, the device transmits a message to the dedicated cloud-based software via the nearest cellular communications tower. A text message is then automatically sent to one or more caretakers ' smartphones, alerting them to early indications of an assault by the client. If various caregivers are present, the first person to react may use the smartphone to give a response text message to all others, notifying them of being with or on the manner to the patient. The doctors could use recordings of coughing to help diagnose an illness. The device issues an alert only to caregivers, because sending an audio file would consume a significant amount of battery power. However, when the wearable sensor batch is recharging, it could be provisioned to forward sound files to the patient's doctor.
\end{abstract}

Keywords-IoT, Machine Learning, Bio patches, Classification and Regression Tree.

\section{INTRODUCTION}

An ease, speedy and effectively available arrangement is expected to give endless hack analysis to individuals in creating countries where its commonness, and death rate because of ceaseless hack, is most noteworthy[1],[3],[5]

. Such a framework should be completely computerized, easy to use, and exceedingly exact so that there are no obstructions to its selection and arrangement. With the cell phone utilization consistently ascending in creating nations, this fills in as a perfect stage on which such a mechanized framework can be produced[2 ],[ 4],[6]. This paper proposes a total programmed unending hack determination calculation dependent on programmed division and grouping of hack and challenge sounds. At the point when executed on

Revised Manuscript Received on July 22, 2019.

R. Velvizhi, Department of CSE, Bharath Institute of Higher Edccation and Research, Chennai, Tamilnadu, India.Email:velvizhisp@gmail.com

D.Jayapriya, Department of CSE, Bharath Institute of Higher Edccation and Research, Chennai, Tamilnadu, India Email:priyajp8@gmail.com

N. Priya, Department of CSE, Bharath Institute of Higher Edccation and Research, Chennai, Tamilnadu, India. Email:priyabiher@gmail.com an installed gadget or a cell phone, it can investigate sound signs acquired from the inherent amplifier and give brief analytic outcome This capacity to give incessant hack conclusion by handling sound flags on a cell phone can be amazingly useful to convey opportune and productive treatment to spots and individuals with constrained or no entrance to healthcare.In this paper, a hack recognizable proof calculation is suggested that can naturally fragment singular hack and challenge sounds and therefore order them and present an interminable hack analysis[7],[ 9], [11]. The point is to build up a calculation utilizing minimal computational assets to enable the calculation to be sent on low- cost cell phones especially in territories where medicinal services administrations are inadequate[8],[ 10] ,[12].

\section{SMART COUGH DETECTION SYSTEM}

The obtaining framework empowers to catch and store information from sensors. signs are not dissected or prepared in this progression, which is performed disconnected. the square graph of the obtaining framework is shown in fig. 1[13], [15],[ 17]. it is actualized as an established obtaining framework by methods for sensors, simple flag molding circuit (front-end), simple to-advanced change, correspondence, and putting away useful squares.

This framework has been enhanced since the new model coordinates an oximeter sensor for estimating, at the same time, the centralization of oxygen in the blood. in any case, the reconciliation of this new sensor has incited the decrease of battery life and furthermore some commotion because of the moderate stockpiling of a few sensors information. in this manner, we proposed to abuse quick access memory card for putting away our information, for example, sd card class 10 fig. 2 introduces our model appearing fundamental segments (sensors).[4] 


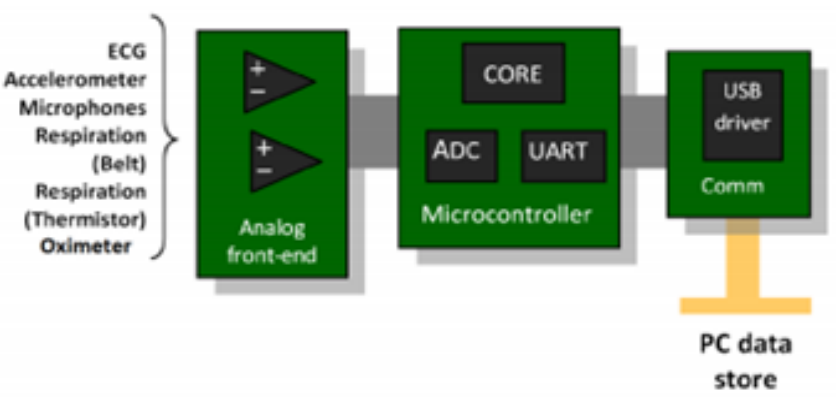

Fig. 1: Block diagram of the acquisition system.

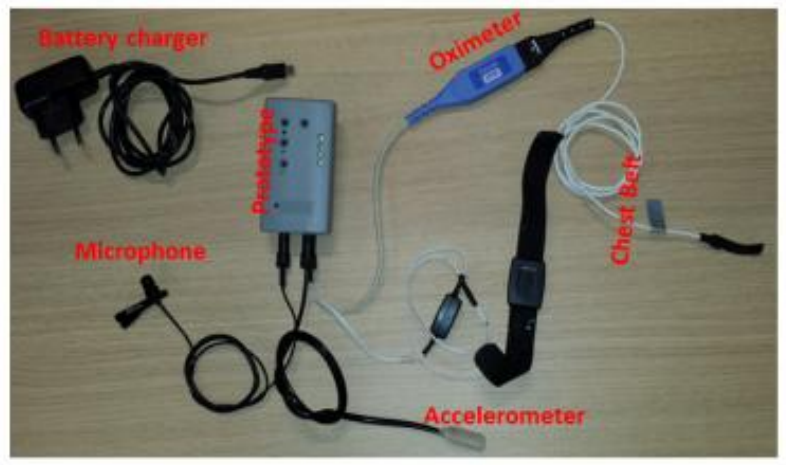

Fig. 2: Sensor-based Cough detection prototype

The System Architecture of the proposed system as shown in figure 3 involves the following steps

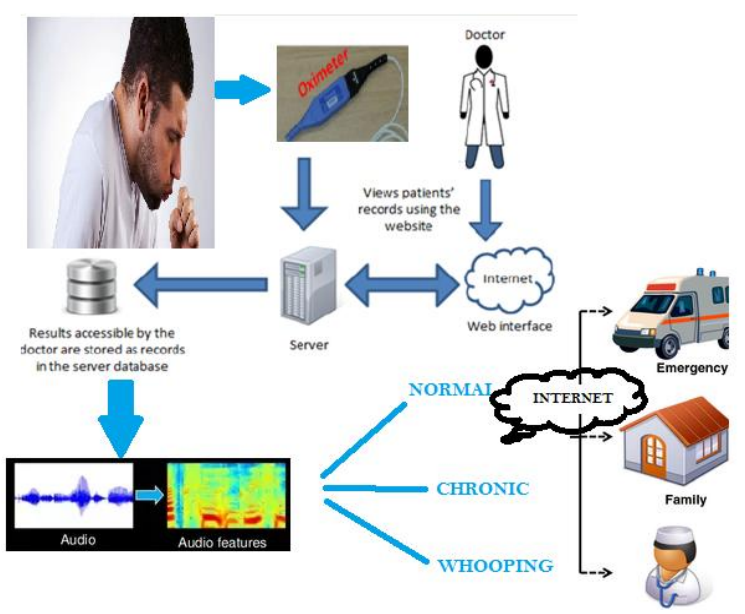

Fig. 3: System Architecture of the proposed system

\section{A. Cough Detection Algorithm}

The general work process for the programmed recognition of hack utilized all through this paper is shown in Fig. 3. [14], [ 16], [18] From the signs caught by a given sensor, or by a few sensors in a multimodal approach, the initial step goes for removing a wide assortment of highlights. Since this prompts a restrictive number of highlights, a stage of dimensionality decrease is important by choosing just the most applicable ones[32],[34],[36]. This is here accomplished dependent on a few estimates got from the Information Theory. At last, an Artificial Neural Network (ANN) based classifier is utilized for demonstrating, precisely, the component appropriations and for illustration the last hack recognition choice.

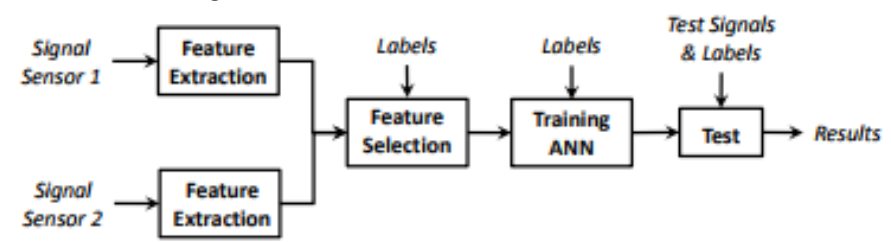

The above-mentioned algorithm has been improved within the main factors:

Accurate cough duration[38],[40]

The previously mentioned calculation permitted to recognize hacks with a high exactness. In any case, in a few circumstances, a similar hack was identified for twice (two hacks distinguished with a similar end time). To conquer this limitation, we begin by recognizing rehashed hacks by contrasting the begin and end times of every two continuous hacks. Surely, if two progressive hacks present a similar end time and two close begin times, we think of one as hack just by keeping the longest hack regarding length. In addition, we register the quantity of hacks every moment.

\section{B. Cough Event Detection}

This comprises in looking at the time between every two progressive hacks. For instance, we think about the end time of the I th hack with the begin time of $(I+1)$ th hack. On the off chance that the distinction esteem is lower than the edge esteem, the both (I and (i+1)) are incorporated into a similar hack occasion. The limit is characterized by applying our calculation on the previously mentioned information. As result, we get a mean edge of $3 \mathrm{~ms}$ that could isolate two hack events.Although the challenging sound regularly pursues a scene of hacking, it isn't really present in all instances of endless hack nor in each spell of hacking, particularly on account of babies. Notwithstanding, in situations where this sound is available, its identification enhances the conclusion of incessant hack and enhance the general exactness a computerized classifier.The structure of the challenging sound identifier pursues a comparable example to the hack finder. Of the 38 chronicles in the database, 10 perpetual hack and 7 non-ceaseless hack accounts are utilized to make the preparation set. The MFCCs, time and recurrence area highlights recorded before are separated from these accounts to make an element vector for a strategic relapse model 


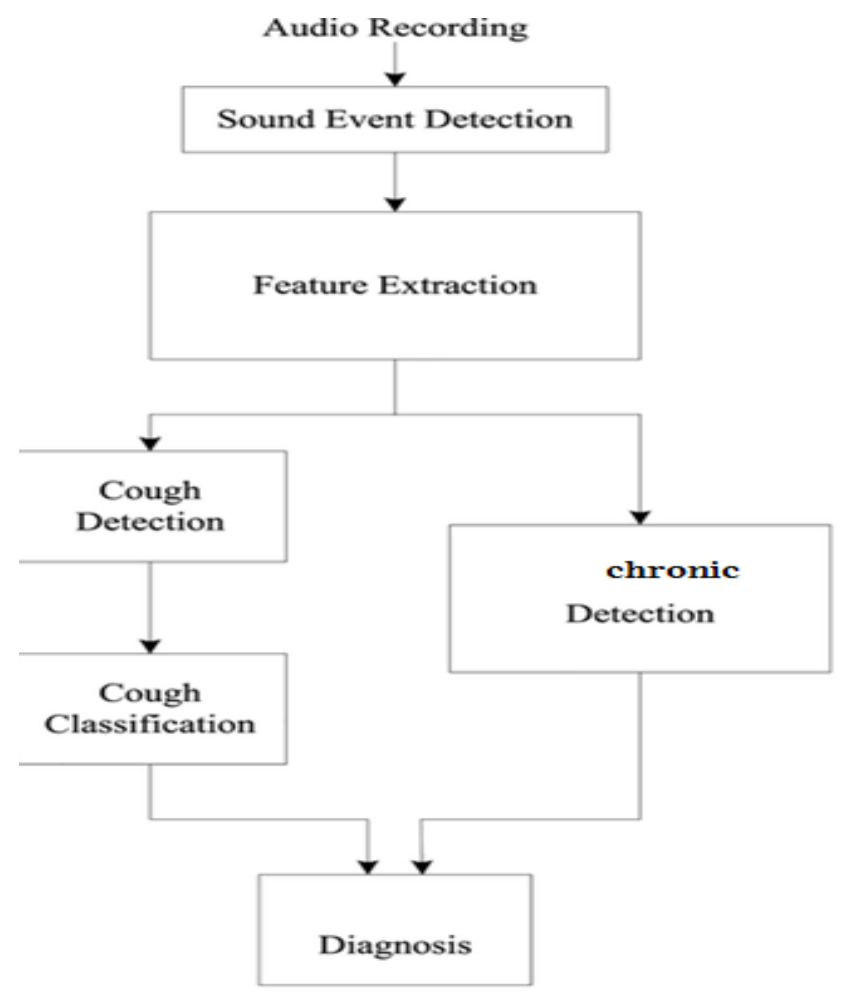

\section{CONCLUSION}

We proposed in this paper another framework that permits to identify and figure hacks utilizing a few sensors: ECG, thermistor, chest belt, oximeter, accelerometer, contact and sound mouthpieces[31],[33],[35]. In view of the caught qualities from these sensors, we connected component extraction and arrangement calculations for distinguishing hacks, which offered a found the middle value of affectability of $94.7 \%$. Our framework permits additionally to separate hack occasions which can be characterized as a gathering of close and progressive hacks. Something else, the acquired outcomes are deciphered and envisioned with a graphical view (GUI) where the identified hack extricates are imagined and sorted out likewise to their comparability as far as sound properties, for example, timbre, hack term and flag vitality. As future work, we intend to include the approval of our model in patients with cystic fibrosis. We plan likewise to quicken the procedure of hack discovery by misusing parallel (GPU) and heterogeneous (Multi-CPU/Multi-GPU).

\section{REFERENCES}

[1] Kumarave A., Rangarajan K.,Algorithm for automaton specification for exploring dynamic labyrinths,Indian Journal of Science and Technology,V-6,I-SUPPL5,PP-4554-4559,Y-2013

[2] P. Kavitha, S. Prabakaran "A Novel Hybrid Segmentation Method with Particle Swarm Optimization and Fuzzy C-Mean Based On Partitioning the Image for Detecting Lung Cancer" International Journal of Engineering and Advanced Technology (IJEAT) ISSN: 2249-8958, Volume-8 Issue-5, June 2019

[3] Kumaravel A., Meetei O.N.,An application of non-uniform cellular automata for efficient cryptography,2013 IEEE Conference on Information and Communication Technologies, ICT 2013,V-,I-,PP-1200-1205,Y-2013

[4] Kumarave A., Rangarajan K.,Routing alogrithm over semi-regular tessellations,2013 IEEE Conference on Information and Communication Technologies, ICT 2013,V-,I-,PP-1180-1184,Y-2013

[5] P. Kavitha, S. Prabakaran "Designing a Feature Vector for Statistical Texture Analysis of Brain Tumor” International Journal of Engineering and Advanced Technology (IJEAT) ISSN: 2249-8958, Volume-8 Issue-5, June 2019

[6] Dutta P., Kumaravel A.,A novel approach to trust based identification of leaders in social networks,Indian Journal of Science and Technology,V-9,I-10,PP--,Y-2016

[7] Kumaravel A., Dutta P.,Application of Pca for context selection for collaborative filtering,Middle - East Journal of Scientific Research,V-20,I-1,PP-88-93,Y-2014

[8] Kumaravel A., Rangarajan K.,Constructing an automaton for exploring dynamic labyrinths,2012 International Conference on Radar, Communication and Computing, ICRCC 2012,V-,I-,PP-161-165,Y-2012

[9] P. Kavitha, S. Prabakaran "Adaptive Bilateral Filter for Multi-Resolution in Brain Tumor Recognition" International Journal of Innovative Technology and Exploring Engineering (IJITEE) ISSN: 2278-3075, Volume-8 Issue-8 June, 2019

[10] Kumaravel A.,Comparison of two multi-classification approaches for detecting network attacks, World Applied Sciences Journal,V-27,I-11,PP-1461-1465,Y-2013

[11] Tariq J., Kumaravel A.,Construction of cellular automata over hexagonal and triangular tessellations for path planning of multi-robots,2016 IEEE International Conference on Computational Intelligence and Computing Research, ICCIC 2016,V-,I-,PP--,Y-2017

[12] Sudha M., Kumaravel A.,Analysis and measurement of wave guides using poisson method,Indonesian Journal of Electrical Engineering and Computer Science,V-8,I-2,PP-546-548,Y-2017

[13] Ayyappan G., Nalini C., Kumaravel A.,Various approaches of knowledge transfer in academic social network, International Journal of Engineering and Technology,V-,I-,PP-2791-2794,Y-2017

[14] Kaliyamurthie, K.P., Sivaraman, K., Ramesh, S. Imposing patient data privacy in wireless medical sensor networks through homomorphic cryptosystems 2016, Journal of Chemical and Pharmaceutical Sciences 92.

[15] Kaliyamurthie, K.P., Balasubramanian, P.C. An approach to multi secure to historical malformed documents using integer ripple transfiguration 2016 Journal of Chemical and Pharmaceutical Sciences 92.

[16] A.Sangeetha,C.Nalini,"Semantic Ranking based on keywords extractions in the web", International Journal of Engineering \& Technology, 7 (2.6) (2018) 290-292

[17] S.V.GayathiriDevi,C.Nalini,N.Kumar,"An efficient software verification using multi-layered software verification tool "International Journal of Engineering \& Technology, 7(2.21)2018 454-457

[18] C.Nalini,ShwtambariKharabe,"A Comparative Study On Different Techniques Used For Finger - Vein Authentication", International Journal Of Pure And Applied Mathematics, Volume 116 No. 8 2017, 327-333, Issn: 1314-3395

[19] M.S. Vivekanandan and Dr. C. Rajabhushanam, "Enabling Privacy Protection and Content Assurance in Geo-Social Networks", International Journal of Innovative Research in Management, Engineering and Technology, Vol 3, Issue 4, pp. 49-55, April 2018.

[20] Dr. C. Rajabhushanam, V. Karthik, and G. Vivek, "Elasticity in Cloud Computing", International Journal of Innovative Research in Management, Engineering and Technology, Vol 3, Issue 4, pp. 104-111, April 2018.

[21] K. Rangaswamy and Dr. C. Rajabhushanamc, "CCN-Based Congestion Control Mechanism In Dynamic Networks", International Journal of Innovative Research in Management, Engineering and Technology, Vol 3, Issue 4, pp. 117-119, April 2018.

[22] Kavitha, R., Nedunchelian, R., "Domain-specific Search engine optimization using healthcare ontology and a neural network backpropagation approach", 2017, Research Journal of Biotechnology, Special Issue 2:157-166

[23] Kavitha, G., Kavitha, R., "An analysis to improve throughput of high-power hubs in mobile ad hoc network" , 2016, Journal of Chemical and Pharmaceutical Sciences, Vol-9, Issue-2: 361-363

[24] Kavitha, G., Kavitha, R., "Dipping interference to supplement throughput in MANET", 2016, Journal of Chemical and Pharmaceutical Sciences, Vol-9, Issue-2: 357-360

[25] Michael, G., Chandrasekar, A.,'Leader election based malicious detection and response system in MANET using mechanism design approach", Journal of Chemical and Pharmaceutical Sciences(JCPS) Volume 9 Issue 2, April - June 2016

[26] Michael, G., Chandrasekar, A.,"Modeling of detection of camouflaging worm using epidemic dynamic model and power spectral density", Journal of Chemical and Pharmaceutical Sciences(JCPS) Volume 9 Issue 2, April - June 2016.

[27] Pothumani, S., Sriram, M., Sridhar, J., Arul Selvan, G., Secure mobile agents communication on intranet,Journal of Chemical and 
Pharmaceutical Sciences, volume 9, Issue 3, Pg No S32-S35, 2016

[28] Pothumani, S., Sriram, M., Sridhar , Various schemes for database encryption-a survey, Journal of Chemical and Pharmaceutical Sciences, volume 9, Issue 3, Pg NoS103-S106, 2016

[29] Pothumani, S., Sriram, M., Sridhar, A novel economic framework for cloud and grid computing, Journal of Chemical and Pharmaceutical Sciences, volume 9, Issue 3, Pg No S29-S31, 2016

[30] Priya, N., Sridhar, J., Sriram, M. "Ecommerce Transaction Security Challenges and Prevention Methods- New Approach" 2016 ,Journal of Chemical and Pharmaceutical Sciences, JCPS Volume 9 Issue 3.page no:S66-S68 .

[31] Priya, N.,Sridhar,J.,Sriram, M."Vehicular cloud computing security issues and solutions" Journal of Chemical and Pharmaceutical Sciences(JCPS) Volume 9 Issue 2, April - June 2016

[32] Priya, N., Sridhar, J., Sriram, M. "Mobile large data storage security in cloud computing environment-a new approach" JCPS Volume 9 Issue 2. April - June 2016

[33] Anuradha.C, Khanna.V, "Improving network performance and security in WSN using decentralized hypothesis testing "Journal of Chemical and Pharmaceutical Sciences(JCPS) Volume 9 Issue 2, April - June 2016.

[34] Anuradha.C, Khanna.V, "A novel gsm based control for e-devices" Journal of Chemical and Pharmaceutical Sciences(JCPS) Volume 9 Issue 2, April - June 2016 .

[35] Anuradha.C, Khanna.V, "Secured privacy preserving sharing and data integration in mobile web environments " Journal of Chemical and Pharmaceutical Sciences(JCPS) Volume 9 Issue 2, April - June 2016.

[36] Sundarraj, B., Kaliyamurthie, K.P. Social network analysis for decisive the ultimate classification from the ensemble to boost accuracy rates 2016 International Journal of Pharmacy and Technology 8

[37] Sundarraj, B., Kaliyamurthie, K.P. A content-based spam filtering approach victimisation artificial neural networks 2016 International Journal of Pharmacy and Technology 83 .

[38] Sundarraj, B., Kaliyamurthie, K.P. Remote sensing imaging for satellite image segmentation 2016 International Journal of Pharmacy and Technology 83 .

[39] Sivaraman, K., Senthil, M. Intuitive driver proxy control using artificial intelligence 2016 International Journal of Pharmacy and Technology $8 \quad 4$.

[40] Sivaraman, K., Kaliyamurthie, K.P. Cloud computing in mobile technology 2016 Journal of Chemical and Pharmaceutical Sciences 92.

[41] Sivaraman, K., Khanna, V. Implementation of an extension for browser to detect vulnerable elements on web pages and avoid click jacking 2016 Journal of Chemical and Pharmaceutical Sciences 92.

\section{AUTHORS PROFILE}

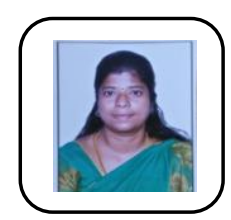

R.Velvizhi, Assistant Professor, Department of Computer Science \& Engineering, Bharath Institute of Higher Education and Research, Chennai, India

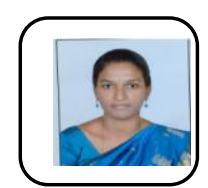

D.Jayapriya,Assistant Professor, Department of Computer Science \& Engineering, Bharath Institute of Higher Education and Research, Chennai, India

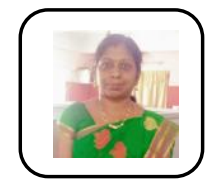

N.Priya,Assistant Professor, Department of Computer Science \& Engineering, Bharath Institute of Higher Education and Research, Chennai, India 